\title{
Membangun model kebijakan melalui analisis psikososial pada penderita HIV/AIDS perempuan di Surabaya
}

\section{Building policy model through psychosocial analyses in HIV/AIDS women in Surabaya}

\author{
M. G. Bagus Ani Putra \\ Fakultas Psikologi, Universitas Airlangga, Surabaya \\ Jalan Dharmawangsa Dalam, Surabaya, 60286, Indonesia \\ E-mail: bagus.ani@psikologi.unair.ac.id
}

\begin{abstract}
This research aims to obtain policy model toward psychosocial analysis to HIV/AIDS women survivors in Surabaya. The model was developed by relation between HIV infection status and psychological condition (religiousness, subjective well being, perception of social support and perception of stress). Data collection technique applied in this research is interview and questionnaire toward 28 HIV/AID women survivors in Surabaya. Subjects were selected from 50 women survivors in Surabaya to gain positive HIV diagnosis. Data analysis method was statistical test with correlation analysis between psychological and medical variable. As the result, there is no correlation between HIV infection status and psychological condition of women survivors in Surabaya. But in a partial analysis, there is a correlation between HIV infection status and religiousness, subjective well being, perception of social support. Some of variables that have partial correlation to be dimensions of model that propose as a basic of policy to treat HIV/AIDS women survivors in Surabaya.
\end{abstract}

Keywords: policy model, women HIV infection status, psychological condition

\begin{abstract}
Abstrak
Penelitian ini bertujuan untuk mendapatkan model kebijakan melalui analisis psikososial pada penderita HIV/ADS perempuan di Surabaya. Model tersebut berdasarkan hubungan antara status infeksi HIV dengan kondisi psikologis (religiusitas, kesejahteraan subyektif, persepsi dukungan sosial dan persepsi tekanan/stress). Metode yang digunakan adalah wawancara dan menyajikan kuesioner kepada 28 perempuan penderita HIV/AIDS di Surabaya yang telah bersedia berpartisipasi dalam penelitian ini. Subyek ini diseleksi dari 50 orang perempuan yang terindikasi infeksi HIV/AIDS di Surabaya untuk menegakkan diagnosis HIV positif. Data kemudian dilakukan uji statistik dengan analisis korelasi antara variabel psikologis dengan variabel medis. Hasil yang didapatkan dalam penelitian ini adalah tidak ada hubungan antara status infeksi HIV dengan kondisi psikologis. Ketika dilakukan analisis parsial didapatkan terdapat hubungan antara status infeksi HIV dengan religiusitas, kesejahteraan subyektif dan persepsi dukungan sosial. Beberapa variabel yang mempunyai hubungan parsial ini kemudian menjadi dimensi-dimensi dalam model yang diajukan sebagai dasar kebijakan untuk penanganan penderita HIV/AIDS perempuan di Surabaya.
\end{abstract}

Kata kunci: model kebijakan, status infeksi HIV perempuan, kondisi psikologis

\section{Pendahuluan}

Merebaknya epidemi HIV/AIDS telah menjadi permasalahan dunia yang membutuhkan penanganan secara komprehensif dengan melibatkan berbagai elemen masyarakat dunia, mulai dari negara, LSM, masyarakat internasional dan PBB. Epidemi HIV/AIDS ini terkonsentrasi di negara-negara berkembang seperti di negara-negara Afrika dan Asia. Di benua Afrika 1,6 juta orang meninggal setiap tahun, sementara di Asia sekitar 8,3 juta orang terinfeksi HIV/AIDS (Widiyatna 2009).

Di Indonesia, menurut data dari Departemen Kesehatan akhir Maret 2008 Kasus AIDS mencapai 11.868 sedangkan infeksi HIV sebanyak 6.130. Data yang dikeluarkan pemerintah ini merupakan data yang telah dilaporkan. Diprediksikan masih banyak orang Indonesia yang terinfeksi HIV, mengingat kasus HIV/AIDS merupakan fenomena gunung es, yang kelihatan hanya di permukaan saja. Hasil estimasi populasi rawan tertular HIV tahun 2006 sebanyak 193.000 orang (Widiyatna 2009). 
Data dari Komisi Penanggulangan AIDS (KPA), secara kumulatif 1 April 1987 sampai dengan 30 September 2012 terdapat 92.251 kasus HIV, 39.434 kasus AIDS, dan 7.293 di antara kasus tersebut mengakibatkan kematian. Jawa Timur provinsi ke tiga terbanyak kasus HIV, yaitu 11.994 kasus dan AIDS 5.257 kasus. Prevalensi kasus AIDS di Jawa Timur per 100.000 penduduk adalah 14.03.

Sementara itu, menurut laporan perkembangan HIV/AIDS triwulan 1 (Januari sampai dengan Maret 2011) adalah sebagai berikut: 1) Rasio kasus AIDS antara laki-laki dan perempuan adalah $3: 2 ; 2$ ) Cara penularan kasus AIDS baru yang dilaporkan melalui heteroseksual (66,95\%), (IDU 23,08\%), perinatal $(5,70 \%)$ dan LSL $(3,42 \%)$; 3) Proporsi kasus AIDS tertinggi dilaporkan pada kelompok umur 30-39 tahun $(33,62 \%)$, disusul kelompok umur 20-29 tahun $(33,05 \%)$ dan kelompok umur 40-49 tahun $(17,09 \%)$; 4) Jumlah total kasus baru HIV positif pada layanan VCT di triwulan 1 tahun 2011 adalah 4.552 kasus (Kemenkes 2011).

Keseriusan dunia dalam menanggulangi HIV/AIDS tercetus dalam Tujuan Pembangunan Millennium (Millennium Development Goals/MDGs) yang disponsori oleh Badan Dunia PBB. Diharapkan MDGs ini dapat tercapai pada tahun 2015. Indonesia termasuk salah satu negara yang ikut menyepakati MDGs bersama 189 negara lainnya, namun hingga saat ini prevalensi HIV/AIDS semakin meningkat. Bila tidak ditangani secara serius Indonesia bisa dianggap gagal dalam mencapai MDGs (Kompas 03/03/2007).

Usia harapan hidup manusia di negara-negara berkembang termasuk Indonesia antara 50-60 tahun. Di negara maju harapan hidup manusia bisa mencapai 80-90 tahun. Bila penduduknya terinfeksi HIV, maka usia harapan hidup akan semakin berkurang. Orang yang terinfeksi HIV masuk dalam kategori masa HIV yaitu masa di mana orang masih bisa produktif (bekerja, belajar, bermain, berolah raga dan aktivitas lainnya), walaupun di tubuhnya sudah terdapat HIV. Masa HIV ini mampu bertahan 5-10 tahun, setelah itu tahap AIDS yaitu di mana sistem kekebalan tubuh manusia mulai menurun sehingga berbagai penyakit dapat menyerangnya, masa AIDS ini bertahan 1-2 tahun.

Persoalan HIV/AIDS bukan hanya persoalan medis tapi juga menyangkut persoalan sosial, psikologi, budaya, ekonomi, hukum, dan pendidikan. Ketiadaan lapangan pekerjaan, biaya pendidikan yang semakin mahal membuat beban hidup masyarakat semakin berat. Demi untuk memenuhi kebutuhan hidup (survival) tidak sedikit masyarakat terutama para perempuan yang mencari nafkah dengan menjual diri, menjajakan diri dengan menjadi pekerja seks, padahal pekerjaan jenis ini mengandung risiko tinggi terkena HIV termasuk kepada para klien atau konsumennya, maka penelitian terhadap HIV/AIDS merupakan hal yang sangat urgen guna menemukan solusi-solusi terbaik.

Menurut penelitian yang dilakukan oleh Tsevat et al. (1999), ODHA juga memiliki keinginan yang besar untuk terus hidup, dan memiliki harapan bahwa kehidupan mereka akan lebih baik daripada kehidupan mereka sebelumnya. Sieff (dalam Myers 2010) juga menyatakan bahwa ketika individu mengetahui dirinya mengidap HIV/AIDS terkadang mereka ingin menghancurkan kehidupan mereka sendiri.

Kebahagiaan merupakan kondisi psikologis yang dirasakan individu secara subjektif yang dicirikan sebagai level emosi positif yang tinggi, dan level emosi negatif yang rendah sebagai indikasi dari interpretasi yang positif terhadap kehidupannya, sehingga dapat memunculkan kepuasan dalam hidupnya (Diener et al. 1999). Penelitian tersebut memaparkan aspek kebahagiaan, bahwa kebahagiaan memiliki dua aspek, yakni aspek afektif dan kognitif. Aspek afektif mewakili pengalaman emosional seperti riang, gembira, senang, dan emosi positif yang lain. Aspek kognitif mewakili evaluasi kognitif dalam kepuasan terhadap berbagai domain dalam kehidupan individu. Berdasarkan aspek kebahagiaan tersebut, rekonstruksi kebahagiaan adalah proses individu dalam membangun kembali kebahagiaannya yang mengindikasikan adanya perubahan kognisi berupa pengembangan penilaian mengenai kebahagiaan, juga perubahan afeksi berupa peningkatan emosi positif yang dirasakan. 
Terkait dengan pengalaman emosional yang dirasakan, Seligman (2004) merumuskan ada tiga emosi positif berdasarkan orientasi waktunya, yakni emosi positif yang ditujukan pada masa lalu, masa sekarang dan masa depan. Emosi positif yang ditujukan pada masa lalu, seperti rasa puas, damai dan bangga. Emosi positif yang ditujukan pada masa sekarang, seperti kenikmatan lahiriah (misalnya kelezatan makanan, kehangatan, dan orgasme) dan kenikmatan yang lebih tinggi seperti senang, gembira, dan nyaman (Seligman 2004). Emosi positif yang ditujukan pada masa depan, seperti optimisme, harapan, kepastian (confidence), kepercayaan (trust), dan keyakinan (faith). Emosi positif pada masa depan ditunjang oleh bagaimana individu memandang masa depannya. Dengan demikian, penelitian ini bertujuan untuk menganalisis hubungan antara status infeksi HIV dengan kondisi psikologis penderita HIV/AIDS perempuan di Surabaya agar mendapatkan model kebijakan yang tepat.

\section{Metode Penelitian}

Data dikumpulkan dari 30 perempuan yang terinfeksi HIV (positif) di Surabaya yang terseleksi dari 50 suspect HIV/AIDS. Kriteria inklusi, jenis kelamin perempuan yang telah menikah. Penelitian ini secara khusus berfokus pada perempuan HIV dan hubungannya dengan fungsi psikologis. Umur responden antara 21 sampai 59 tahun dan tingkat pendidikan di atas Sekolah Menengah Pertama, serta status perkawinan.

Skala religiusitas yang digunakan menggunakan kuesioner dari Glock \& Stark (1998) dengan dimensi: keyakinan, praktek agama, pengalaman, pengetahuan, dan konsekuensi. Sedangkan skala kesejahteraan subyektif (subjective well-being) yang digunakan berdasarkan teori dari Diener et al. (1999). Adapun skala persepsi terhadap tekanan digunakan untuk mengukur tingkat stress dalam waktu 1 bulan dengan pengembangan skala dari Cohen \& Janicki-Deverts (2012).

Peneliti menyiapkan 4 kuesioner tersebut dalam satu set untuk kepentingan pre-test dan post test untuk menguji model intervensi psikologis yang dilakukan. Intervensi psikologis yang dilakukan adalah pelatihan dan focus group discussion (FGD) tentang: penerimaan diri (self acceptance) dan hubungan dan komunikasi interpersonal.

Setelah dilakukan intevensi psikologis ini maka akan diuji efektivitasnya sehingga bisa mendapatkan model intervensi sebagai dasar kebijakan untuk penderita HIV/AIDS perempuan di Surabaya. Selain diuji dengan membandingkan antara pre test dan post test kuesioner tersebut, efektivitas intervensi dilakukan dengan analisis CD4 setiap subyek dengan memperhatikan ambang batas minimal CD4, yaitu 410. Artinya, ketika ada skor CD4 mendekati 410.

\section{Hasil Penelitian dan Pembahasan}

Setelah data pre-test dan post-test terkumpul maka dilakukan analisis statistik. Analisis data secara keseluruhan dilakukan menggunakan perangkat lunak SPSS for Windows versi 16.0. Deskripsi subyek penelitian ini dikategorikan berdasarkan usia, tingkat pendidikan, status perkawinan dan agama. Gambaran keseluruhan subyek penelitian adalah sebagai berikut:

Tabel 1.

Deskripsi data subyek penelitian berdasarkan kategori usia

\begin{tabular}{llll}
\hline No & Usia (tahun) & Jumlah & Persentase (\%) \\
\hline 1. & $17-25$ (remaja akhir) & 1 & 3.57 \\
2. & $26-35$ (dewasa awal) & 11 & 39.3 \\
3. & $36-45$ (dewasa akhir) & 12 & 42.9 \\
4. & 46-55 (lansia) & 4 & 14.3 \\
& Total & 28 & 100.0 \\
\hline
\end{tabular}


Tabel 2.

Deskripsi data subyek penelitian berdasarkan kategori tingkat pendidikan

\begin{tabular}{llll}
\hline No & Tingkat pendidikan & Jumlah & Persentase (\%) \\
\hline 1. & SD & 3 & 10.7 \\
2. & SLTP & 6 & 21.4 \\
3. & SLTA & 16 & 57.1 \\
4. & Diploma & 1 & 3.6 \\
5. & S1 & 2 & 7.1 \\
& Total & 28 & 100.0 \\
\hline
\end{tabular}

Tabel 3.

Deskripsi data subyek penelitian berdasarkan kategori Status pernikahan

\begin{tabular}{llll}
\hline No & Status & Jumlah & Persentase (\%) \\
\hline 1. & Menikah & 12 & 42.9 \\
2. & Janda & 16 & 57.1 \\
& Total & 28 & 100.0 \\
\hline
\end{tabular}

Tabel 4.

Deskripsi data subyek penelitian berdasarkan kategori agama

\begin{tabular}{llll}
\hline No & Agama & Jumlah & Persentase (\%) \\
\hline 1. & Islam & 27 & 96.4 \\
2. & Nasrani & 1 & 3.6 \\
& Total & 28 & 100.0 \\
\hline
\end{tabular}

Tabel 5.

Deskripsi data variabel penelitian

\begin{tabular}{lrrrr}
\hline frequency & $\begin{array}{c}\text { Religiusitas } \\
\text { pre }\end{array}$ & $\begin{array}{c}\text { Kesejahteraan } \\
\text { subyektif pre }\end{array}$ & Religiusitas post & $\begin{array}{c}\text { Kesejahteraan } \\
\text { subyektif post }\end{array}$ \\
\cline { 2 - 6 } $\mathrm{N}$ & 28 & 28 & 28 & 28 \\
\cline { 2 - 5 }$\quad$ Missing & 0 & 0 & 0 & 0 \\
Mean & 38.57 & 49.46 & 37.86 & 48.79 \\
Mode & 40 & 49 & $40^{\mathrm{a}}$ & $47^{\mathrm{a}}$ \\
Std. Deviation & 4.167 & 6.763 & 4.284 & 8.355 \\
Variance & 17.365 & 45.739 & 18.349 & 69.804 \\
Minimum & 31 & 33 & 28 & 29 \\
Maximum & 44 & 63 & 44 & 63 \\
\hline
\end{tabular}

Deskripsi data variabel penelitian berdasarkan skor hipotetik dengan skor empiris pre-test masing-masing variabel penelitian adalah seperti pada Tabel 6-9.

Tabel 6.

Deskripsi data empirik dan data hipotetik variabel religiusitas pre-test

\section{Ukuran Empirik Hipotetik}

\begin{tabular}{lcc}
\hline Skor Minimal & 31 & 11 \\
Skor Maksimal & 44 & 44 \\
Rerata & 38.57 & 27.5 \\
Standar Deviasi & 4.167 & 5.5 \\
\hline
\end{tabular}


Tabel 7.

Deskripsi data empirik dan data hipotetik variabel kesejahteraan subyektif pre-test

\begin{tabular}{lcc}
\hline \multicolumn{1}{c}{ Ukuran } & Empirik & Hipotetik \\
& & \\
\hline Skor Minimal & 33 & 17 \\
Skor Maksimal & 63 & 68 \\
Rerata & 49.46 & 42.85 \\
Standar Deviasi & 4.763 & 8.5 \\
\hline
\end{tabular}

Tabel 8.

Deskripsi data empirik dan data hipotetik variabel dukungan sosial pre-test

\begin{tabular}{lcc}
\hline \multicolumn{1}{c}{ Ukuran } & Empirik & Hipotetik \\
& & \\
\hline Skor Minimal & 16 & 6 \\
Skor Maksimal & 24 & 24 \\
Rerata & 18.96 & 15 \\
Standar Deviasi & 2.236 & 3 \\
\hline
\end{tabular}

Tabel 9.

Deskripsi data empirik dan data hipotetik variabel stress pre-test

\begin{tabular}{lcc}
\hline \multicolumn{1}{c}{ Ukuran } & Empirik & Hipotetik \\
& & \\
\hline Skor Minimal & 13 & 10 \\
Skor Maksimal & 29 & 40 \\
Rerata & 22.36 & 25 \\
Standar Deviasi & 4.002 & 5 \\
\hline
\end{tabular}

Deskripsi data variabel penelitian berdasarkan skor hipotetik dengan skor empiris post-test masing-masing variabel penelitian adalah seperti tabel 10-13.

Tabel 10.

Deskripsi data empirik dan data hipotetik variabel religiusitas post-test

\begin{tabular}{lcc}
\hline \multicolumn{1}{c}{ Ukuran } & Empirik & Hipotetik \\
& & \\
\hline Skor Minimal & 28 & 11 \\
Skor Maksimal & 44 & 44 \\
Rerata & 37.86 & 27.5 \\
Standar Deviasi & 4.284 & 5.5 \\
\hline
\end{tabular}

Tabel 11.

Deskripsi data empirik dan data hipotetik variabel kesejahteraan subyektif post-test

\begin{tabular}{lcc}
\hline \multicolumn{1}{c}{ Ukuran } & Empirik & Hipotetik \\
& & \\
\hline Skor Minimal & 29 & 17 \\
Skor Maksimal & 63 & 68 \\
Rerata & 48.79 & 42.85 \\
Standar Deviasi & 8.355 & 8.5 \\
\hline
\end{tabular}


Tabel 12.

Deskripsi data empirik dan data hipotetik variabel dukungan sosial post-test

\begin{tabular}{ccc}
\hline Ukuran & Empirik & Hipotetik \\
& & \\
\hline Skor Minimal & 15 & 6 \\
Skor Maksimal & 23 & 24 \\
Rerata & 18.71 & 49.46 \\
Standar Deviasi & 2.492 & 6.763 \\
\hline
\end{tabular}

Tabel 13.

Deskripsi data empirik dan data hipotetik variabel stress post-test

\begin{tabular}{lcc}
\hline \multicolumn{1}{c}{ Ukuran } & Empirik & Hipotetik \\
& & \\
\hline Skor Minimal & 15 & 10 \\
Skor Maksimal & 35 & 40 \\
Rerata & 21.86 & 25 \\
Standar Deviasi & 4.866 & 5 \\
\hline
\end{tabular}

Deskripsi data empiris dan hipotesis variabel religiusitas di atas menunjukkan bahwa skor minimal data empiris jauh lebih tinggi dari skor hipotetis. Skor rerata empiris dalam variabel ini pun lebih tinggi dari skor hipotetisnya. Dapat disimpulkan bahwa sampel dalam penelitian ini menunjukkan tingkat religiusitas yang tinggi.

Deskripsi data empiris dan hipotetis variabel kesejahteraan subyektif menunjukkan bahwa skor minimal data empiris lebih tinggi dari skor hipotetis. Skor rerata empiris dalam variabel ini pun lebih tinggi dari skor hiptetisnya. Dapat disimpulkan bahwa sampel dalam penelitian ini memiliki persepsi bahwa mereka cukup sejahtera secara psikologis.

Deskripsi data empiris dan hipotetis variabel dukungan sosial menunjukkan bahwa skor minimal data empiris lebih tinggi dari skor hipotetis. Skor rerata empiris dalam variabel ini pun lebih tinggi dari skor hipotesisnya. Dapat disimpulkan bahwa sampel dalam penelitian ini menunjukkan persepsi bahwa mereka mendapatkan dukungan sosial yang mencukupi.

Deskripsi data empiris dan hipotesis variabel stress menunjukkan bahwa skor minimal data empiris lebih tinggi dari skor hipotetis namun skor rerata empiris dalam variabel ini lebih rendah dari skor hipotetisnya. Dapat disimpulkan bahwa sampel dalam penelitian ini menunjukkan tingkat stress yang relatif rata-rata seperti orang kebanyakan.

Data variabel penelitian ini kemudian dikategorikan dalam lima kelompok kategori atau lima jenjang atau yang lazim disebut stan-five. Lima kategori ini masing-masing diberi label mulai dari "sangat rendah", "rendah", "sedang", "tinggi", sampai "sangat tinggi". Setiap kategori diberi batasan skor sebagai acuan norma.

Setelah mengetahui batasan jenjang dari tiap kategori maka subjek penelitian dapat dikelompokkan menurut skor yang didapatkan di setiap alat ukur penelitian. Tabel 14-15 adalah deskripsi subjek penelitian berdasarkan kategori nilai yang didapatkan sebelum (pre-test) intervensi dilakukan dan sesudah (post-test) intervensi dilakukan pada variabel religiusitas, kesejahteraan subyektif, dukungan sosial, dan stress. 
Tabel 14.

Kategori nilai subjek penelitian dalam stan-five (pre-test)

\begin{tabular}{lcccc}
\hline & Norma Kategori & Kategori & & Jumlah \\
Variabel & & & 0 & 0 \\
\hline Religiusitas & $\mathrm{X}>44.82$ & Sangat Tinggi & 10 & 35.71 \\
& $40.65<\mathrm{X} \leq 44.82$ & Tinggi & 9 & 32.14 \\
& $36.49<\mathrm{X} \leq 40.65$ & Sedang & 6 & 21.43 \\
& $32.32<\mathrm{X} \leq 36.49$ & Rendah & 3 & 10.71 \\
\hline Subjective Well- & $\mathrm{X} \leq 32.32$ & Sangat Rendah & 1 & 3.57 \\
Being & $\mathrm{X}>59.60$ & Sangat Tinggi & 1 & 32.14 \\
& $52.84<\mathrm{X} \leq 59.60$ & Tinggi & 9 & 35.71 \\
& $46.08<\mathrm{X} \leq 52.84$ & Sedang & 10 & 21.43 \\
& $39.32<\mathrm{X} \leq 46.08$ & Rendah & 6 & 7.14 \\
\hline Dukungan sosial & $\mathrm{X} \leq 39.32$ & Sangat Rendah & 2 & 3.57 \\
& $\mathrm{X}>22.31$ & Sangat Tinggi & 1 & 28.57 \\
& $20.08<\mathrm{X} \leq 22.31$ & Tinggi & 8 & 35.71 \\
& $17.84<\mathrm{X} \leq 20.08$ & Sedang & 10 & 32.14 \\
& $15.61<\mathrm{X} \leq 17.84$ & Rendah & 9 & 0 \\
\hline Stress & $\mathrm{X} \leq 15.61$ & Sangat Rendah & 0 & 7.14 \\
& $\mathrm{X}>28.36$ & Sangat Tinggi & 2 & 21.43 \\
& $24.36<\mathrm{X} \leq 28.36$ & Tinggi & 6 & 39.29 \\
& $20.36<\mathrm{X} \leq 24.36$ & Sedang & 11 & 28.57 \\
& $16.36<\mathrm{X} \leq 20.36$ & Rendah & 8 & 3.57 \\
\hline
\end{tabular}

Tabel 15.

Kategori nilai subjek penelitian dalam stan-five (post-test)

\begin{tabular}{lcccc}
\hline Variabel & Norma Kategori & Kategori & & J \\
\hline Religiusitas & & & Jumlah & \\
& $\mathrm{X}>44.29$ & Sangat Tinggi & 0 & 0 \\
& $40.00<\mathrm{X} \leq 44.29$ & Tinggi & 7 & 25 \\
$35.72<\mathrm{X} \leq 40.00$ & Sedang & 13 & 46.43 \\
& $31.43<\mathrm{X} \leq 35.72$ & Rendah & 6 & 21.43 \\
& $\mathrm{X} \leq 31.43$ & Sangat Rendah & 2 & 7.14 \\
\hline Subjective Well- & $\mathrm{X}>61.32$ & Sangat Tinggi & 1 & 3.57 \\
Being & $52.97<\mathrm{X} \leq 61.32$ & Tinggi & 9 & 32.14 \\
& $44.61<\mathrm{X} \leq 52.97$ & Sedang & 11 & 39.29 \\
& $36.26<\mathrm{X} \leq 44.61$ & Rendah & 5 & 17.86 \\
& $\mathrm{X} \leq 36.26$ & Sangat Rendah & 2 & 7.14 \\
\hline Dukungan sosial & $\mathrm{X}>22.45$ & Sangat Tinggi & 2 & 7.14 \\
& $19.96<\mathrm{X} \leq 22.45$ & Tinggi & 9 & 32.14 \\
& $17.46<\mathrm{X} \leq 19.96$ & Sedang & 7 & 25.00 \\
& $14.97<\mathrm{X} \leq 17.46$ & Rendah & 10 & 35.71 \\
$\mathrm{X}$ & $\leq 14.97$ & Sangat Rendah & 0 & 0 \\
\hline Stress & $\mathrm{X}>29.16$ & Sangat Tinggi & 1 & 3.57 \\
& $24.29<\mathrm{X} \leq 29.16$ & Tinggi & 7 & 25.00 \\
& $19.43<\mathrm{X} \leq 24.29$ & Sedang & 10 & 35.71 \\
& $14.56<\mathrm{X} \leq 19.43$ & Rendah & 10 & 35.71 \\
$\mathrm{X} \leq 14.56$ & Sangat Rendah & 0 & 0 \\
\hline
\end{tabular}

Hasil analisis data pre test di atas menunjukkan bahwa pada variabel religiusitas jumlah subyek yang berada dalam ketegori sangat tinggi sama dengan $0(0 \%)$, tinggi 10 orang $(35.71 \%)$, sedang 9 orang (32.14\%), rendah 6 orang $(21.43 \%)$, dan sangat rendah 3 orang $(10.71 \%)$. Jumlah subyek pada 
variabel kesejahteraan subyektif yang berada dalam ketegori sangat tinggi berjumlah 1 orang (3.57\%), tinggi 9 orang $(32.14 \%)$, sedang 10 orang $(35.71 \%)$, rendah 6 orang $(21.43 \%)$, dan sangat rendah 2 orang $(7.14 \%)$.

Pada variabel dukungan sosial, jumlah subyek yang berada dalam ketegori sangat tinggi berjumlah 1 orang (3.57\%), tinggi 8 orang (28.57\%), sedang 10 orang (35.71\%), rendah 9 orang $(32.14 \%)$, dan sangat rendah tidak ada. Pada variabel stress, jumlah subyek yang berada dalam ketegori sangat tinggi berjumlah 2 orang $(7.14 \%)$, tinggi 6 orang $(21.43 \%)$, sedang 11 orang $(39.29 \%)$, rendah 8 orang (28.57\%), dan sangat rendah 1 orang $(3.57 \%)$.

Hasil analisis data post test menunjukkan bahwa pada variabel religiusitas jumlah subyek yang berada dalam ketegori sangat tinggi tidak ada, tinggi 7 orang (25\%), sedang 13 orang (46.43\%), rendah 6 orang $(21.43 \%)$, dan sangat rendah 2 orang $(7.14 \%)$. Jumlah subyek pada variabel kesejahteraan subyektif yang berada dalam ketegori sangat tinggi berjumlah 1 orang (3.57\%), tinggi 9 orang (32.14\%), sedang 11 orang $(39.29 \%)$, rendah 5 orang (17.86\%), dan sangat rendah 2 orang $(7.14 \%)$.

Pada variabel dukungan sosial, jumlah subyek yang berada dalam ketegori sangat tinggi berjumlah 2 orang $(7.14 \%)$, tinggi 9 orang (32.14\%), sedang 7 orang (25\%), rendah 10 orang (35.71\%), dan sangat rendah tidak ada. Pada variabel stress, jumlah subyek yang berada dalam ketegori sangat tinggi berjumlah 1 orang (3.57\%), tinggi 7 orang (25\%), sedang 10 orang (35.71\%), rendah 10 orang $(35.71 \%)$, dan sangat rendah tidak ada.

Uji normalitas untuk menentukan normalitas data dilakukan untuk menentukan teknik statistik yang akan digunakan dalam uji perbedaan variabel penelitian ini. Teknik statistik parametrik secara teoritis mensyaratkan asumsi data berdistribusi normal, selain mensyaratkan data berjenis interval atau rasio. Uji normalitas dengan teknik Kolmogorov-Smirnov dilakukan menggunakan SPSS 16.0 for Windows. Data disebut normal apabila nilai signifikansi $>0,05$, sebaliknya jika nilai signifikansi $<0,05$ maka asumsi normalitas tidak terpenuhi sehingga analisis statistik harus menggunakan teknik statistik nonparametrik (Field, 2009).

Hasil uji normalitas data penelitian menunjukkan ada data yang berdistribusi normal adalah data variabel kesejahteraan subyektif (pre-test), tingkat stress (pre-test), religiusitas (pre-test), dan tingkat stress (post-test). Hasil ini berarti asumsi normalitas data tidak dipenuhi oleh keseluruhan data variabel penelitian, sehingga teknik analisis statistik yang digunakan selanjutnya adalah teknik nonparametrik, yaitu Spearman's rank correlation (Spearman's Rho). Hasil analisis data menggunakan menggunakan teknik statistik non-parametrik The Wilcoxon Signied-Rank bertujuan menguji perbedaan dua kelompok data dari variabel penelitian yang berasal dari subyek yang sama, di mana distrubusi data bersifat tidak normal. Sedangkan teknis statistik non-parametrik Spearman's rank correlation (Spearman's Rho) menguji korelasi antara dua data variabel penelitian yang berasal dari subyek yang sama, di mana distribusi data bersifat tidak normal.

Hasil analisis menunjukkan bahwa uji perbedaan data keempat variabel yaitu religiusitas, kesejahteraan subyektif, dukungan sosial, dan stress sebelum intervensi (pre-test) dengan setelah intervensi (post-test) tidak menunjukkan perbedaan yang signifikan. Simpulan hasil analisis data ini mengacu pada nilai signifikansi yang semuanya di atas nilai signifikansi 0.05 (variabel religiusitas $\mathrm{Z}=-1.229, \mathrm{p}=0.219$; kesejahteraan subyektif $\mathrm{Z}=-0.417 \mathrm{p}=0.676$; variabel dukungan sosial $\mathrm{Z}=-323$ $\mathrm{p}=0.747$; stress $\mathrm{Z}=-0.605, \mathrm{p}=0.545$ ). 
Tabel 16.

Analisis medis uji laboratorium pasca intervensi psikologis

\begin{tabular}{cccccccccc}
\hline & \multicolumn{1}{c}{ GOL } & \multicolumn{4}{c}{ HB } & & \multicolumn{3}{c}{ DIFF( LY-STAB- } \\
NO & KODE & DARAH & ERI CD4 & 9/dl & HCT\% & WBC PLT & SEG ) \\
\hline 1 & P01 & B & 4,41 & 15 & 14,4 & 41,4 & 5,6 & 291 & $22,9 / 59,2 / 17,9$ \\
2 & P02 & A & 2,6 & 101 & 11,2 & 30,0 & 4,3 & 354 & $27,3 / 61,4 / 11,3$ \\
3 & P03 & O & 2,87 & 239 & 12,6 & 35,2 & 4,2 & 366 & $37,2 / 51,8 / 11,0$ \\
4 & P05 & O & 2,2 & 208 & 8,9 & 26 & 2,5 & 319 & $43,6 / 47,4 / 9$ \\
5 & P06 & O & 4,25 & 158 & 12,6 & 37,5 & 9,2 & 288 & $27,3 / 63,6 / 9,1$ \\
6 & P07 & O & 3,47 & 310 & 12,6 & 35,6 & 6,5 & 325 & $32,5 / 61,3 / 6,2$ \\
7 & P08 & A & 3,21 & 101 & 13,8 & 37,8 & 5,3 & 325 & $40,5 / 49,8 / 9,7$ \\
8 & P09 & B & 3,11 & 297 & 12,9 & 35,1 & 6,1 & 237 & $44,8 / 46,8 / 8,4$ \\
9 & P11 & O & 3,97 & 319 & 11,2 & 32,8 & 5,7 & 258 & $42,5 / 49,4 / 8,1$ \\
10 & P12 & A & 4,16 & 266 & 14,0 & 39,1 & 4,2 & 268 & $34,9 / 51,4 / 13,7$ \\
11 & P13 & A & 4,09 & 8 & 14,1 & 39,6 & 6,5 & 244 & $33,9 / 58,5 / 7,6$ \\
12 & P14 & A & 2,77 & 17 & 12,6 & 33,3 & 4,4 & 290 & $32,7 / 55,8 / 11,5$ \\
13 & P15 & B & 2,24 & 146 & 10,6 & 29,2 & 4,7 & 287 & $29,9 / 62,3 / 7,8$ \\
14 & P16 & AB & 3,25 & 207 & 11,6 & 33,1 & 6,6 & 404 & $29,2 / 61,9 / 8,9$ \\
15 & P18 & O & 3,58 & 3 & 12,6 & 35,4 & 6,9 & 175 & $25,8 / 64,5 / 9,7$ \\
16 & P19 & A & 3,13 & 62 & 13,0 & 35,4 & 5,1 & 275 & $32,6 / 56,2 / 11,2$ \\
17 & P20 & O & 4,22 & 79 & 14,4 & 39,4 & 5,6 & 173 & $33,4 / 57,6 / 9$ \\
18 & P21 & O & 3,81 & 268 & 10,8 & 32,6 & 3,7 & 246 & $36,6 / 50,3 / 13,1$ \\
19 & P22 & O & 2,71 & 73 & 11,8 & 32,1 & 5,4 & 306 & $40,7 / 44,2 / 15,1$ \\
20 & P23 & O & 2,66 & 51 & 10,2 & 29,5 & 10,4 & 459 & $19,4 /$ \\
21 & P24 & O & 2,60 & 250 & 11,0 & 30,7 & 6,5 & 260 & $30 / 62,8 / 7,2$ \\
22 & P25 & O & 3,95 & 20 & 13,1 & 37,6 & 4,3 & 317 & $22,4 / 61,7 / 15,9$ \\
23 & P26 & A & 4,12 & 79 & 11,5 & 35,2 & 4,4 & 303 & $32,9 / 48,4 / 18,7$ \\
24 & P27 & O & 2,5 & 80 & 11,3 & 32,3 & 5,3 & 267 & $34,3 / 48,6 / 17,1$ \\
25 & P28 & B & 3,23 & 354 & 14,2 & 38,6 & 5,6 & 281 & $31,3 / 53,6 / 15,1$ \\
26 & P29 & O & 2,91 & 110 & 12,5 & 33,4 & 6,5 & 219 & $30,5 / 63,8 / 5,7$ \\
27 & P31 & O & 3,79 & 125 & 13,0 & 37,7 & 4,1 & 169 & $30,4 / 58,6 / 11$ \\
28 & P32 & A & 2,7 & 65 & 11,3 & 31,6 & 2,3 & 130 & $30,6 / 43,3 / 26,1$ \\
\hline & & & & & & & & & \\
\hline
\end{tabular}

Dari data tersebut, hanya terdapat 10 subyek (bertanda kuning) dari 28 subyek yang skor CD4 berada di atas 200 dan mendekati skor 410 . Artinya terdapat $35.7 \%$ subyek yang mempunyai CD4 mendekati batas minimal normal setelah mengikuti intervensi psikologis.

Tabel 17.

Analisis korelasi data variabel psikologis dan uji medis

\begin{tabular}{ccccccccccc}
\hline No & Subyek & $\begin{array}{c}\text { Rlg1 } \\
(\mathbf{4 4})\end{array}$ & $\begin{array}{c}\text { SWB1 } \\
(\mathbf{6 8})\end{array}$ & $\begin{array}{c}\text { Sos1 } \\
(\mathbf{2 4})\end{array}$ & $\begin{array}{c}\text { Stres1 } \\
(\mathbf{4 0})\end{array}$ & $\begin{array}{c}\text { Rlg2 } \\
(\mathbf{4 4})\end{array}$ & $\begin{array}{c}\text { SWB2 } \\
(\mathbf{6 8})\end{array}$ & $\begin{array}{c}\text { Sos2 } \\
(\mathbf{2 4})\end{array}$ & $\begin{array}{c}\text { Stres2 } \\
(\mathbf{4 0})\end{array}$ & CD4 \\
\hline 1 & P25 & 39 & 49 & 19 & 26 & 38 & 51 & 21 & 27 & 20 \\
2 & P31 & 32 & 49 & 16 & 19 & 31 & 43 & 16 & 20 & 125 \\
3 & P28 & 44 & 47 & 21 & 22 & 44 & 61 & 21 & 15 & 354 \\
4 & P27 & 40 & 55 & 18 & 20 & 37 & 47 & 16 & 22 & 80 \\
5 & P26 & 40 & 47 & 18 & 22 & 36 & 51 & 18 & 24 & 79 \\
6 & P16 & 44 & 52 & 21 & 29 & 44 & 47 & 21 & 29 & 207 \\
7 & P21 & 35 & 58 & 18 & 19 & 36 & 57 & 19 & 17 & 268 \\
8 & P09 & 40 & 63 & 22 & 24 & 39 & 53 & 23 & 20 & 297 \\
9 & P12 & 42 & 42 & 22 & 13 & 42 & 63 & 22 & 19 & 266 \\
10 & P08 & 38 & 49 & 17 & 27 & 37 & 47 & 15 & 24 & 101 \\
11 & P29 & 42 & 55 & 17 & 29 & 43 & 52 & 19 & 16 & 110
\end{tabular}




\begin{tabular}{ccccccccccc}
12 & P01 & 44 & 55 & 24 & 25 & 40 & 30 & 18 & 26 & 15 \\
13 & P18 & 42 & 54 & 16 & 17 & 44 & 52 & 17 & 17 & 3 \\
14 & P05 & 40 & 33 & 22 & 20 & 40 & 54 & 21 & 17 & 208 \\
15 & P23 & 33 & 45 & 21 & 27 & 33 & 29 & 16 & 35 & 51 \\
16 & P11 & 33 & 59 & 17 & 24 & 35 & 43 & 20 & 24 & 319 \\
17 & P02 & 31 & 56 & 21 & 18 & 36 & 56 & 21 & 17 & 101 \\
18 & P13 & 38 & 42 & 19 & 20 & 40 & 55 & 18 & 20 & 8 \\
19 & P22 & 36 & 40 & 19 & 21 & 42 & 52 & 21 & 18 & 73 \\
20 & P14 & 40 & 53 & 17 & 23 & 39 & 38 & 15 & 17 & 17 \\
21 & P15 & 31 & 53 & 16 & 21 & 28 & 53 & 17 & 22 & 146 \\
22 & P03 & 43 & 45 & 22 & 17 & 44 & 54 & 23 & 16 & 239 \\
23 & P06 & 36 & 51 & 18 & 28 & 35 & 37 & 19 & 26 & 158 \\
24 & P19 & 38 & 49 & 18 & 21 & 35 & 49 & 18 & 22 & 62 \\
25 & P20 & 43 & 51 & 17 & 22 & 40 & 47 & 16 & 28 & 79 \\
26 & P07 & 42 & 39 & 18 & 21 & 32 & 55 & 15 & 22 & 310 \\
27 & P23 & 33 & 52 & 17 & 28 & 33 & 38 & 17 & 27 & 51 \\
28 & P24 & 41 & 42 & 20 & 23 & 37 & 52 & 21 & 25 & 250 \\
\hline
\end{tabular}

Berdasarkan data tersebut maka jika kita memperhatikan tanda kuning, yaitu data medis yang dianggap skor CD4 tinggi (200-400 berdasarkan norma kelompok) maka terdapat korelasi yang cukup tinggi antara status infeksi HIV dengan kehidupan religiusitas, kesejahteraan subyektif dan dukungan sosial, namun tidak ada korelasi antara status infeksi HIV dengan perceived stress.

Hal ini menunjukkan bahwa jawaban dari hipotesis adalah sebagai berikut; 1) Ada hubungan antara status infeksi HIV dengan religiusitas penderita. Artinya, subyek dalam penelitian ini ketika mempunyai status HIV semakin mempunyai tingkat religiusitas yang tinggi. 2) Ada hubungan antara status infeksi HIV dengan kesejahteraan subyektif penderita. Artinya, subyek dalam penelitian ini ketika mempunyai status HIV semakin mempunyai tingkat kesejahteraan subyektif yang tinggi. Para subyek mengaku merasa cukup sejahtera secara psikologis dengan kondisi saat ini meski menyandang status infeksi HIV. 3) Ada hubungan antara status infeksi HIV dengan dukungan sosial penderita. Artinya, subyek dalam penelitian ini ketika mempunyai status HIV semakin mempunyai persepsi terhadap dukungan sosial yang tinggi. Para subyek mengaku mempunyai dukungan sosial dari lingkungan keluarga dan lingkungan sosial lainnya terhadap statusnya sebagai penderita HIV. Ada kalanya mereka mengaku tidak mendapat dukungan sosial dari pasangan (suami) yang sebagian besar penyakit itu mereka dapatkan dari suami (pasangan) yang mayoritas adalah drug abuser. 4) Tidak ada hubungan antara status infeksi HIV dengan stress. Artinya, subyek dalam penelitian ini ketika mempunyai status HIV tidak merasa mempunyai tingkat stress yang tinggi. 5) Secara keseluruhan, tidak ada hubungan antara status infeksi HIV dengan kondisi psikologis penderita perempuan.

Analisis data dalam penelitian ini yang menguji perbedaan variabel religiusitas sebelum dan sesudah dilakukan intervensi menunnjukkan hasil tidak ada perbedaan antara data pre-test dengan data posttest $(\mathrm{Z}=-1.229, \mathrm{p}=0.219)$. Deskripsi data penelitian empiris dan hipotetis menunjukkan bahwa skor rerata empiris pre-test maupun post-test untuk variabel religiusitas menunjukkan rerata yang lebih tinggi dari skor hipotetisnya. Hal ini menunjukkan bahwa sampel penelitian menunjukkan tingkat religiusitas yang di atas rata-rata. Hal ini juga didukung oleh data bahwa sampel yang tingkat religiusitasnya sedang sampai tinggi (meski tidak ada yang sangat tinggi) mencakup $67.85 \%$ (data pre-test) dan $71.47 \%$ (data post-test).

Tingkat stress sampel dalam penelitian ini menunjukkan tingkat yang rata-rata yang ditunjukkan sampel yang berada dalam ketegori stress sedang hingga sangat rendah mencakup $71.43 \%$ (data pretest) dan $71.42 \%$ (data post-test). Data ini dapat ditafsirkan bahwa sampel dalam penelitian ini tidak mengalami stress yang berat dalam kehidupan sehati-harinya.

Tingkat religiusitas sampel penelitian yang cukup tinggi sesuai dengan gambaran Ironson et al. (2006) yang menyatakan bahwa orang yang didiagnosis HIV menunjukkan tingkat spiritualitas yang 
meningkat dari waktu ke waktu. Ironson et al. (2006) menjelaskan bahwa spiritualitas dalam berbagai penelitian empiris meunjukkan sebagai faktor penting kesejahteraan mental. Spiritualitas juga menunjang individu untuk beradaptasi dan menghadapi tantangan hidup yang berat, termasuk menghadapi penyakit yang dideritanya. Pandangan ini sesuai dengan data penelitian ini yang menunjukkan tingkat kesejahteraan subyektif sampel penelitian yang di atas rerata hipotetis. Apabila dikaitkan dengan tingkat religiusitas yang juga reratanya di atas rerata hipotetis, maka religiusitas berperan menghindarkan subyek menjadi tidak secara sejahtera secara subyektif. Religiusitas dengan demikian menjadi sebuah pola adaptasi (spirituality coping) menghadapi dampak psikososial ketika individu didiagnosis mengidap HIV (Zimet et al. 1988). Nilai, ajaran, sikap, perilaku, dan ritus religius bagi setiap individu yang mengidap HIV, termasuk yang menyatakan tidak beragama, menjadi kerangka berpikir individu sehingga dapat menerima, beradaptasi, bangkit, dan menyesuaikan diri dengan diagnosis HIV yang dialaminya.

Religiusitas juga memberikan penguatan terhadap dukungan sosial karena religiusitas didapatkan dari lingkungan sosial sebagai mesosystem (Brofenbrenner 1979). Lingkungan sosial, utamanya di luar keluarga justru memberikan penguatan religiusitas yang tinggi dibandingkan microsystem. Hal ini yang diperoleh subyek penelitian dari lingkungan sosial sehingga dinyatakan dukungan sosialnya dipersepsikan tinggi, namun kenyataan dalam penelitian ini menunjukkan bahwa tidak terdapat hubungan yang signifikan antara tingkat stress yang dipersepsikan oleh subyek dengan status infeksi HIV karena rata-rata subyek telah menderita infeksi HIV positif selama 5 tahun. Hal ini membuat kondisi subyek telah menyesuaikan diri dengan penyakit yang dideritanya. Temuan ini senada yang diutarakan oleh Berger et al. (2001) yang menyatakan bahwa lamanya perolehan status infeksi HIV membuat penderita tidak lagi mempersepsikan stress pada kondisi dirinya karena telah terjadi penerimaan diri atau internalisasi kondisi. Sebaliknya, penelitian ini mematahkan hasil penelitian yang dilakukan oleh Lipsitz et al. (1994) bahwa status infeksi HIV membuat penderitanya mengalami tekanan psikologis dari lingkungan sosialnya. Hal ini disebabkan nilai atau tingkat religiusitas penderita HIV positif dalam penelitian dikategorikan tinggi sebagai dasar dari kehidupan pribadinya.

Tingkat religiusitas sampel penelitian yang di atas rerata dalam penelitian ini menurut peneliti juga dipengaruhi oleh ciri masyarakat Indonesia yang bersifat religius. Masyarakat Indonesia sejak kecil memang diajarkan dan ditanamkan untuk meyakini dan hidup dengan nilai-nilai religiusitas. Masyarakat Indonesia yang religius juga berarti masyarakat Indonesia cenderung menempatkan nilainilai religiusitas sebagai nilai-nilai yang penting dalam kehidupan. Hal ini yang dapat menjelaskan mengapa rerata skor religiusitas sampel penelitian ini cenderung tinggi.

Hasil analisis data uji perbedaan menunjukkan tidak ada perbedaan skor religiusitas pre-test dengan post-test. Ada beberapa penjelasan mengapa hal tersebut terjadi. Pertama, pengukuran variabel religiusitas dalam penelitian ini dilakukan pada saat sebelum intervensi dilakukan (pre-test) dan tiga hari setelah intervensi dilakukan. Tidak adanya perbedaan bisa disebabkan karena terlalu dekatnya jarak waktu pengukuran pre-test dan post-test sehingga cenderung menggunakan pola menjawab yang sama (carry-effect). Kondisi ini sama dengan hasil temuan penelitian yang menyatakan bahwa tidak ada hubungan yang signifikan antara status infeksi HIV dengan kondisi psikologis penderita perempuan. Hal ini karena pengaruh pemberian intervensi dan post test yang berjarak waktu terlalu singkat.

Berdasarkan hasil dan pembahasan penelitian maka terdapat model (hubungan antar variabel) yang dapat dijadikan dasar kebijakan terhadap penderita HIV/AIDS perempuan di Surabaya sebagai hasil implikasi teoritis seperti pada Gambar 1. 


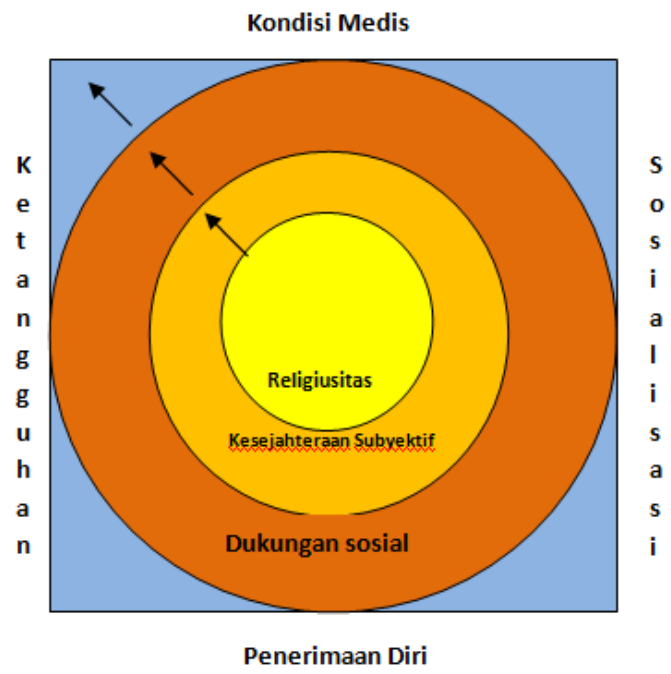

Gambar 1.

Penerimaan diri: Model (hubungan antar variabel) yang dapat dijadikan dasar kebijakan terhadap penderita HIV/AIDS

Pada kajian sebelumnya, Ironson et al. (2006) menyatakan bahwa orang yang didiagnosis HIV menunjukkan tingkat spiritualitas yang meningkat dari waktu ke waktu. Ironson et al. (2006) menjelaskan bahwa spiritualitas dalam berbagai penelitian empiris menunjukkan sebagai faktor penting kesejahteraan mental. Oleh karena itu model yang disajikan berdasarkan variabel-variabel penelitian adalah sebagai berikut; 1) Lingkar utama adalah religiusitas. Apabila religiusitas penderita HIV/AIDS semakin tinggi atau membesar maka lingkaran yang lain setelahnya juga meningkat atau membesar. Religiusitas juga menunjang individu untuk beradaptasi dan menghadapi tantangan hidup yang berat, termasuk menghadapi penyakit yang dideritanya. Religiusitas dengan demikian menjadi sebuah pola adaptasi (spirituality coping) menghadapi dampak psikososial ketika individu didiagnosis mengidap HIV (Carver et al. 1989). 2) Lingkar kedua adalah kesejahteraan subyektif. Dengan hasil penelitian yang menyatakan bahwa religiusitas akan berdampak terhadap kesejahteraan mental/ psikologis seseorang penderita. Artinya, religiusitas mempunyai dimensi-dimensi yang mengarah kepada kesejahteraan subyektif (Ironson et al. 2006). 3) Lingkar ketiga adalah persepsi dukungan sosial. Broffenbrenner (1979) menyatakan bahwa religiusitas merupakan ajaran atau nilai yang diterima oleh individu di lingkungan microsystem (keluarga) dan mesosystem (lingkungan sosial). Apabila nilai-nilai religiusitas semakin besar maka semakin tinggi persepsi terhadap dukungan sosial bagi para penderita HIV/AIDS.

Apabila lingkaran utama (religiusitas) membesar maka akan secara berurutan akan membesarkan lingkaran kedua (kesejahteraan subyektif) dan ketiga (persepsi terhadap dukungan sosial). Selanjutnya secara simultan pula membesarkan persegi atau kotak yang terdiri dari kondisi medis/ fisik, penerimaan diri, kemampuan bersosialisasi dan ketangguhan (resiliency) penderita HIV/AIDS.

\section{Simpulan}

Berdasarkan hasil penelitian maka dapat disimpulkan bahwa ada hubungan antara status infeksi HIV dengan religiusitas penderita. Subyek dalam penelitian ini ketika mempunyai status HIV semakin mempunyai tingkat religiusitas yang tinggi. Ada hubungan antara status infeksi HIV dengan kesejahteraan subyektif penderita. Subyek dalam penelitian ini ketika mempunyai status HIV semakin mempunyai tingkat kesejahteraan subyektif yang tinggi. Para subyek mengaku merasa cukup sejahtera secara psikologis dengan kondisi saat ini meski menyandang status infeksi HIV. Ada hubungan antara status infeksi HIV dengan dukungan sosial penderita. Subyek dalam penelitian ini ketika mempunyai status HIV semakin mempunyai persepsi terhadap dukungan sosial yang tinggi. Para subyek mengaku mempunyai dukungan sosial dari lingkungan keluarga dan lingkungan sosial lainnya terhadap statusnya sebagai penderita HIV. Tidak ada hubungan antara status infeksi HIV 
dengan stress. Artinya, subyek dalam penelitian ini ketika mempunyai status HIV tidak merasa mempunyai tingkat stress yang tinggi. Secara keseluruhan, tidak ada hubungan antara status infeksi HIV dengan kondisi psikologis penderita perempuan. Terdapat model (hubungan antar variabel penelitian) sebagai dasar kebijakan terhadap penderita HIV/AIDS perempuan di Surabaya. Variabel dalam model tersebut antara lain; religiusitas, kesejahteraan subyektif, persepsi dukungan sosial, kondisi fisik/medis, penerimaan diri, kemampuan bersosialisasi dan ketangguhan (resiliency).

\section{Daftar Pustaka}

Berger BE, Ferrans CE \& Lashley FR (2001) Measuring stigma in people with HIV: Psychometric Assessment of the HIV Stigma Scale. Research in Nursing \& Health 24: 518-529.

Bronfenbrenner U (1979) The ecology of human development: Experiments by nature and design. Cambridge: Harvard University Press.

Carver C, Scheier M, \& Weintraub J (1989) Assessing coping strategies: A theoretically based approach. Journal of Personality and Social Psychology 56: 267-390.

Cohen S \& Janicki-Deverts D (2012) Who's stressed? Distributions of psychological stress in the United States in probability samples from 1983, 2006, and 2009. Journal of Applied Social Psychology 42(6): 1320-1334.

Diener E, Suh EM, Lucas RE, \& Smith HL (1999) Subjective well-being: Three decades of progress. Psychological Bulletin 125 (2): 276.

Glock C \& Stark R (1998) American piety. Berkeley: University of California.

Ironson G, Solomon GF, Balbin EG, O’Cleirigh C, George A, Kumar M, Larson D, \& Woods TE (2006) The Ironson-woods spirituality/religiousness Index is associated with long survival, health behaviors, less distress, and low cortisol in people with HIV/AIDS. Annals of Behavioral Medicine: A publication of the Society of Behavioral.

Kemenkes RI. (2011) Ringkasan laporan kesehatan nasional tahun 2011.

Kompas. 3 Maret (2007) Hal 8. HIV/AIDS dan kesehatan Indonesia.

Kompas. 3 Maret (2007) MDGs dan Komitmen Pemerintah.

Lipsitz JD, Williams JBW, Rabkin JG, Remien RH Bradburry M, el Sadr W, Goetz R, Sorrell S, Gorman JM (1994) Psychopathology in male and female intravenous drug users with and without HIV infection. American Journal of Psychiatry 151:1662-1668.

Myers HF (1996) The social resources and social supports questionnaire: A multidimensional inventory. In Jones RL (Ed) Handbook of Tests and Measurements for Black Populations 2:427-441. Hampton, VA: Cobb \& Henry Publishers.

Seligman MEP (2004) Can happiness be taught? Daedalus: Spring.

Tsevat MD, Sherman SN, McElwee JA, Mandell KL, Simbartl LA, Sonnenberg FA, and Fowler Jr. FJ (1999) The will to live among HIV-infected patients. Annals of Internal Medicine:194-198.

Widiyatna (2009) Mencermati prevalensi HIV/AIDS. The Learning University: Universitas Negeri Malang.

Zimet GD, Dahlem NW, Zimet SG, \& Farley GK (1988) The multidimensional scale of perceived social support. Journal of personality assessment 52(1): 30-41. 